WellBeing International

WBI Studies Repository

$11-20-2009$

\title{
Investigation of Van Gogh-like 2 mRNA Regulation and Localisation in Response to Nociception in the Brain of Adult Common Carp (Cyprinus carpio)
}

\author{
Siobhan C. Reilly \\ University of Liverpool \\ Anja Kipar \\ University of Liverpool \\ David J. Hughes \\ University of Liverpool \\ John P. Quinn \\ University of Liverpool \\ Andrew R. Cossins \\ University of Liverpool
}

See next page for additional authors

Follow this and additional works at: https://www.wellbeingintlstudiesrepository.org/acwp_vsm

Part of the Animal Studies Commons, Other Animal Sciences Commons, and the Other Genetics and Genomics Commons

\section{Recommended Citation}

Reilly, S. C., Kipar, A., Hughes, D. J., Quinn, J. P., Cossins, A. R., \& Sneddon, L. U. (2009). Investigation of Van Gogh-like 2 mRNA regulation and localisation in response to nociception in the brain of adult common carp (Cyprinus carpio). Neuroscience letters, 465(3), 290-294.

This material is brought to you for free and open access by WellBeing International. It has been accepted for inclusion by an authorized administrator of the WBI Studies Repository. For more information, please contact wbisr-info@wellbeingintl.org.

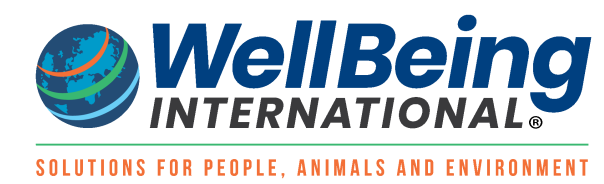


Authors

Siobhan C. Reilly, Anja Kipar, David J. Hughes, John P. Quinn, Andrew R. Cossins, and Lynne U. Sneddon 


\title{
Investigation of Van Gogh-like 2 mRNA Regulation and Localisation in Response to Nociception in the Brain of Adult Common Carp (Cyprinus carpio)
}

\author{
Siobhan C. Reilly, Anja Kipar, David J. Hughes, John P. Quinn, Andrew R. Cossins, and \\ Lynne U. Sneddon \\ University of Liverpool
}

KEYWORDS

Vang/2, fish, nociception, telencephalon (forebrain)

\begin{abstract}
The Van Gogh-like 2 (vang/2) gene is typically associated with planar cell polarity pathways, which is essential for correct orientation of epithelial cells during development. The encoded protein of this gene is a transmembrane protein and is highly conserved through evolution. Van Gogh-like 2 was selected for further study on the basis of consistent regulation after a nociceptive stimulus in adult common carp and rainbow trout in a microarray study. An in situ hybridisation was conducted in the brain of mature common carp (Cyprinus carpio), 1.5 and $3 \mathrm{~h}$ after a nociceptive stimulus comprising of an acetic acid injection to the lips of the fish and compared with a saline-injected control. The vang/2 gene was expressed in all brain regions, and particularly intensely in neurons of the telencephalon and in ependymal cells. In the cerebellum, a greater number $(P=0.018)$ of Purkinje cells expressed vang/2 after nociception $(n=7)$ compared with controls $(n=5)$. This regulation opens the possibility that vang/2 is involved in nociceptive processing in the adult fish brain and may be a novel target for central nociception in vertebrates.
\end{abstract}

Van Gogh-like 2 (vang/2) is a member of the Van Gogh (Vang) or strabismus (Stbm) family of genes, which are associated with the planar cell polarity (PCP) pathway [23]. Vang/2 has been reported in several types of cell, and is particularly well expressed in epithelial, mesodermal and mesenchymal cells, although it has also been implicated in the migration of cranial motor neurons in the hindbrain of fish [13]. In the developing mouse central nervous system, vang/2 messenger RNA (mRNA) is preferentially expressed close to the ventricles, where it influences the closure of the neural tube [28]. After the neural tube has closed, other anatomical regions where vangl2 mRNA is localised are: the cerebral cortex, dorsal root ganglia (DRG), olfactory epithelia, retina and the optic nerve [30]. Despite vang/2's principal association with planar cell polarity (PCP) pathways, there is also potential for a post-natal involvement in sensory processing, due to the influences on transcription factors, as well as its intriguing location in DRG and the forebrain. Furthermore, the role of vang/2 and Wnt signalling may have as yet unrecognised importance in the adult brain. Disruption of Wnt signalling has been proposed to cause neurological disorders [3], and have effects on synaptic plasticity in the hippocampus [2]. 
Nociception, the sensory mechanism for detecting potentially injurious stimuli that elicits pain sensation in humans, has been relatively recently explored in fish and is associated with molecular changes in the brain [25]. Since vang/2 was shown to be up-regulated in fish brains after a nociceptive event in a microarray study [25], the aim of this study is to examine where vang/2 mRNA is expressed in the brain of adult common carp, and whether transcript expression levels respond to noxious stimulation. The expression levels were assessed after 1.5 and $3 \mathrm{~h}$ with in situ hybridisation (ISH) using a specific riboprobe complementary to the vang/2 transcript. Based upon previous research, it is hypothesized that mRNA encoding vangl2 will be primarily localised to epithelial cells and the forebrain areas of the fish brain which are important in mammalian nociception.

Fig. 1. Common carp, sagittal section of the whole brain with RNA-ISH with vang/2 riboprobe, Papanicolaou's haematoxylin counterstain. Expression of vang/2 mRNA is seen ubiquitously throughout the brain. (1) Dorsal telencephalon; (2) ventral telencephalon; (3) optic chiasma; (4) thalamus; (5) tectum; (6) torus longitudinalis; (7) hypothalamus; (8) valvula cerebella; (9) corpus cerebella; (10) lobus caudalis; (11) tegmentum; (12) medulla oblongata; (13) cerebellar crest; (14) vagal lobe.

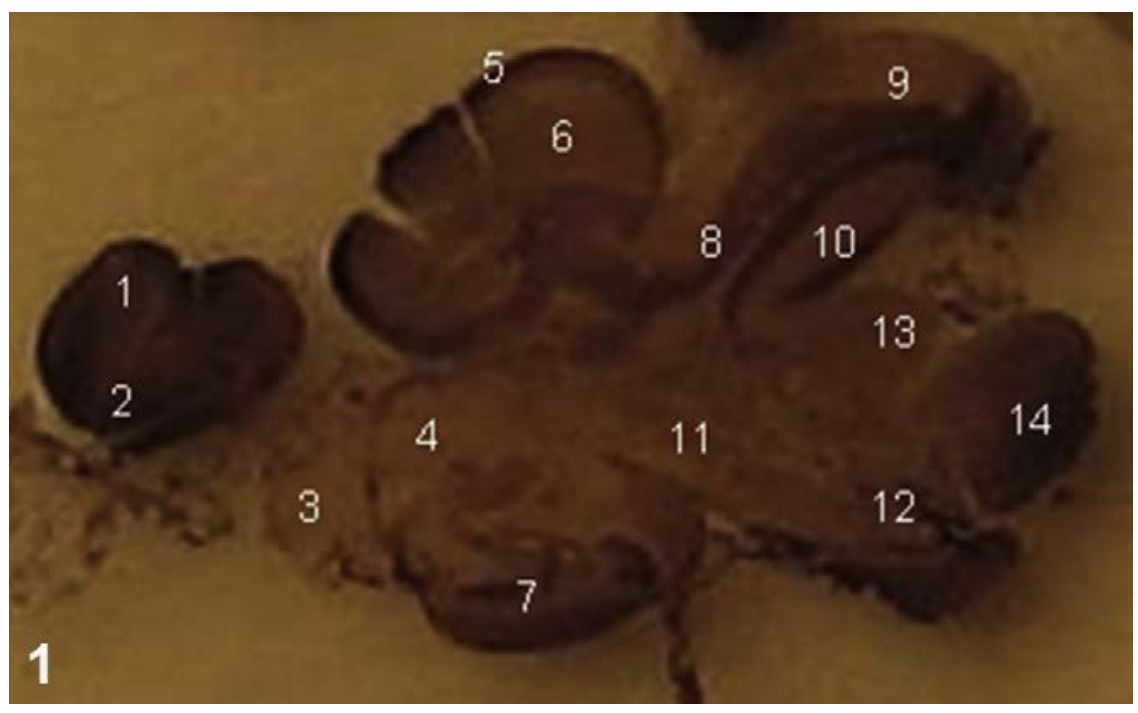

All experiments were conducted in an ethical and humane way under approval from Liverpool University's Local Ethical Committee and under Home Office (UK) licensing. Common carp (Cyprinus carpio) were obtained and held as previously described [25]. During the experiment, individual fish were anaesthetised in aerated water dosed with benzocaine $(1 \mathrm{ml} / \mathrm{l}$ of a $1 \mathrm{~g} / 30 \mathrm{ml}$ ethanol solution). Sterile physiological saline $(0.9 \% \mathrm{NaCl} ; 0.1 \mathrm{ml})$ was injected subcutaneously into the upper and lower frontal lips of the fish belonging to the control group and the same volume of acetic acid ( $5 \%$ acid, diluted in saline) was injected into the treatment groups. The fish were returned to their home tank to recover from the anaesthesia. The control and treatment samples were collected at $1.5 \mathrm{~h}(n=3)$ and $3 \mathrm{~h}(n=6)$ time points after the procedure since common carp show adverse behavioural signs in vivo at these time points [26]. The brain was dissected as a whole organ and fixed for $24 \mathrm{~h}$ in buffered $4 \%$ paraformaldehyde (pH 7.4). Transverse sections of approximately $1.5 \mathrm{~mm}$ were prepared from the brain and embedded in paraffin wax. Sections of $3-5 \mu \mathrm{m}$ thickness were cut onto Polysine ${ }^{\mathrm{TM}}$ glass slides (VWR International bvba, Leuven, Belgium) and stained with haematoxylin-eosin (HE) or dried for 1 week for use in ISH. 
Primers used to construct the 190 base vangl2 riboprobe for RNA-ISH were 5'-CGGTCCCTTTGGTGACTCTA-3' and 5'-CCTTGGATGTGGTAGCCGTT-3'. These primers were based on the carpBASE 2.0 consensus sequence of subgroup ID 679-1 (http://legr.liv.ac.uk), which shares $97 \%$ identity with the zebrafish vang/2 mRNA sequence (GenBank accession no. AF428249). After ligation into a plasmid vector (TOPO TA Cloning ${ }^{\circledR}$ Kit pCR ${ }^{\circledR}$ IITOPO ${ }^{\circledR}$; Invitrogen BV, Groningen, NL), in vitro transcription of a digoxigenin-labeled riboprobe was performed, using an SP6/T7 polymerase system (DIG RNA Labeling Kit; Roche Diagnostics $\mathrm{GmbH}$, Mannheim, Germany) according to the manufacturer's instructions.

Fig. 2. Common carp, telencephalon (' 1 ' and '2' in Fig. 1) RNA-ISH with vang/2 riboprobe, Papanicolaou's haematoxylin counterstain. (A) Expression of vang/2 mRNA is mainly seen towards the dorsal, anterior section of the forebrain (AF: anterior forebrain; PF: posterior forebrain). (B) Closer view of the positive neurons in the area dorsalis telencephali pars dorsalis of the anterior forebrain. (C) Closer view of the positive neurons in the area dorsalis telencephali, pars centralis of the posterior forebrain.

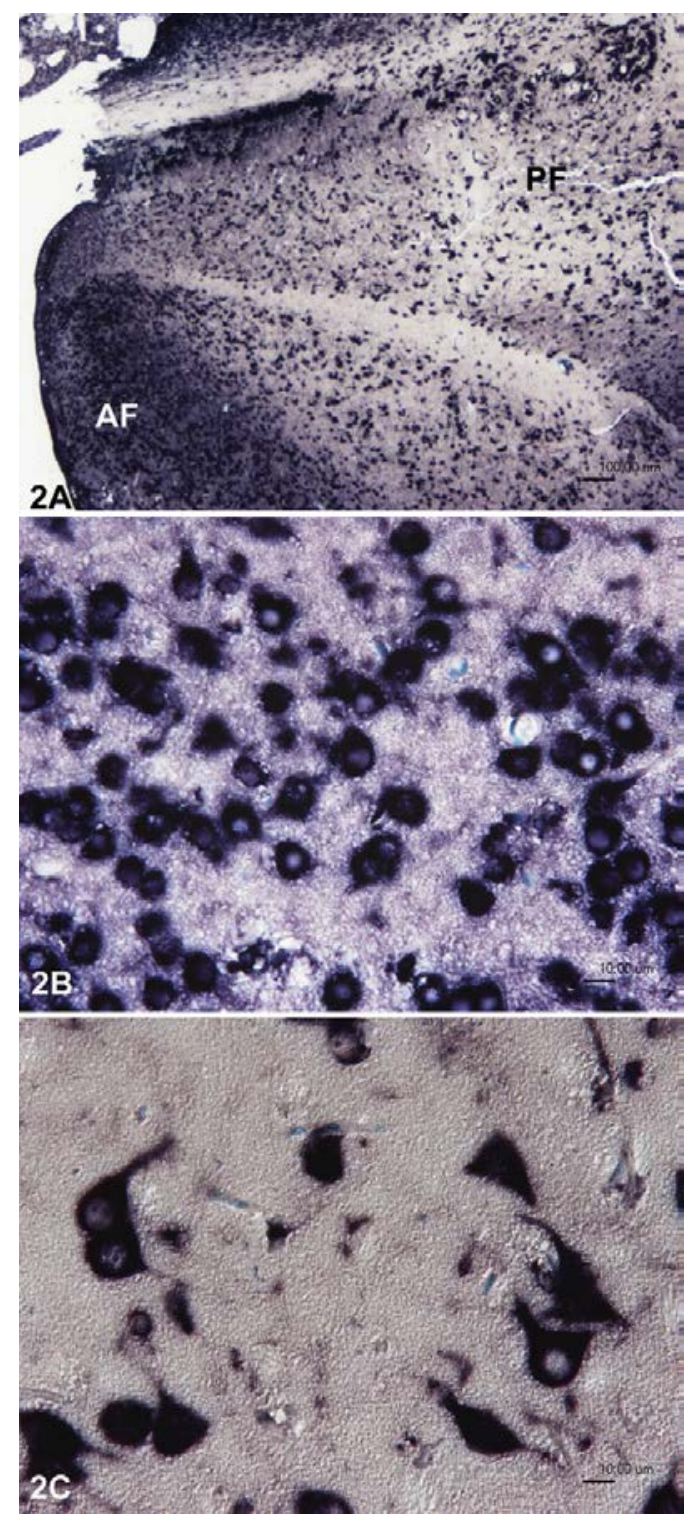


Fig. 3. Common carp, RNA-ISH with vang/2 riboprobe, Papanicolaou's haematoxylin counterstain. (A) Midbrain, tectum mesencephali (' 5 ' in Fig. 1). The organisation of the tectum is labeled (a) leptmeninx/arachnoidea, (b) stratum fibrosum marginale (molecular layer), (c) stratum opticum, (d) stratum fibrosum et griseum superficiale, (e) stratum griseum centrale, (f) stratum album centrale, (g) stratum periventriculare. (B) Midbrain, ventral thalamus ('4' in Fig. 1). All neurons exhibit strong vang/2 mRNA expression. (C) Cerebellum ('9' in Fig. 1). Neurons in both the molecular layer (ML) and the granular layer $(\mathrm{GL})$ as well as the large Purkinje cells (arrows) are positive for vangl2 mRNA. Meningeal cells (arrow head) also exhibit a positive signal. (D) Ventricle (V) and valvula cerebelli (CV) ('8' in Fig. 1). Ependymal cells (EC) that boarder the ventricles express vangl2 mRNA. Neurons in the valvula cerebelli are also positive.
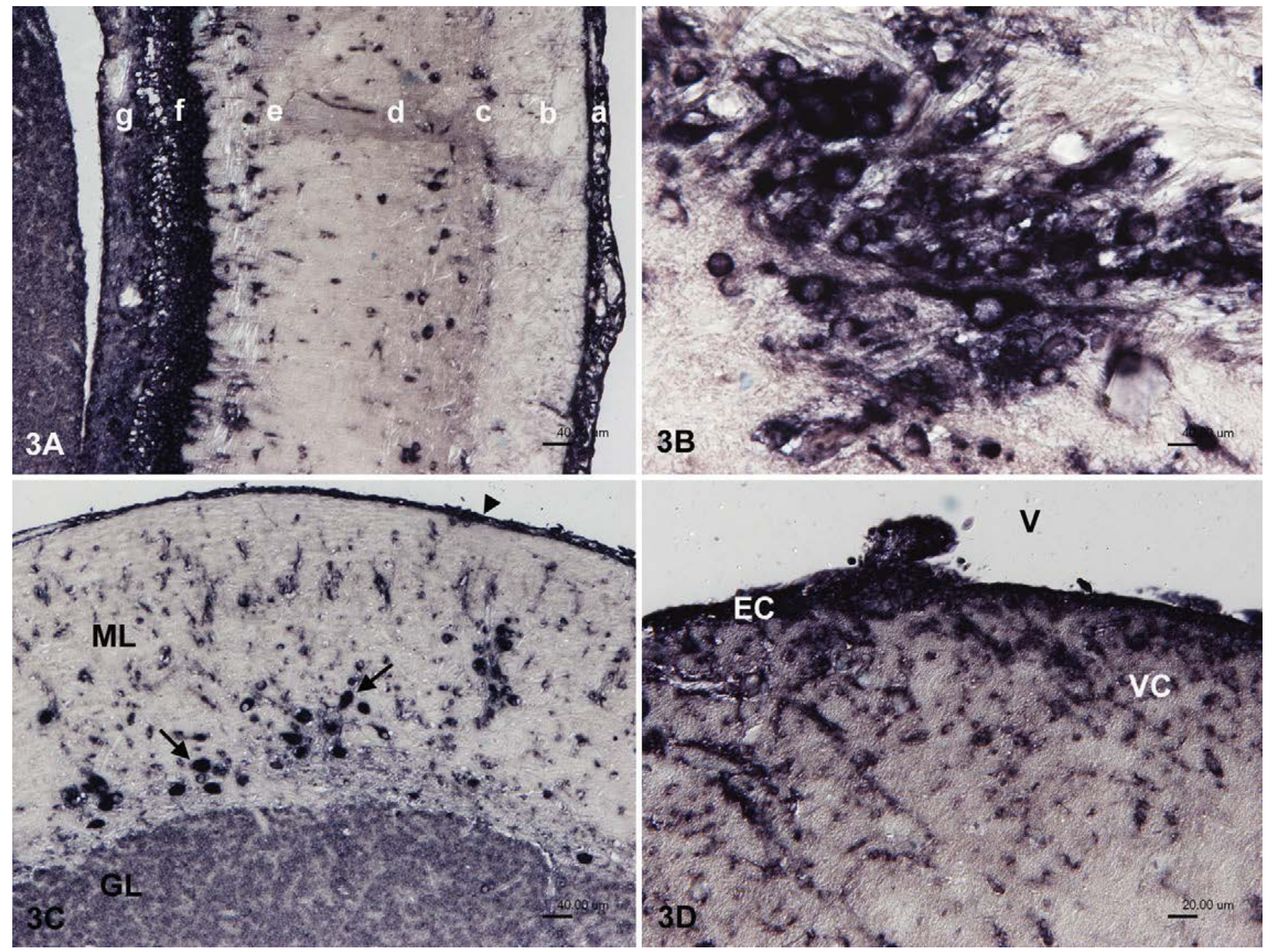

ISH was conducted using the same method as described by Kipar et al. [16] using sense and antisense. Slides were deparaffinised and digested in proteinase $\mathrm{K}(1 \mu \mathrm{g} / \mathrm{ml})$ at $37^{\circ} \mathrm{C}$ for $15 \mathrm{~min}$. This was followed by postfix, acetylation and prehybridisation incubations. Hybridisation was performed at $37^{\circ} \mathrm{C}$ for $18 \mathrm{~h}$ and the riboprobe concentration was $1 \mu \mathrm{l} / 500 \mu \mathrm{l}$ hybridisation mix. After hybridisation, slides were washed and stained with Anti-DIG-AKAP antibody (1:200) (Boehringer; Berkshire, UK) and nitroblue tetrazoliumchloride (Sigma-Aldrich; Poole, UK). A 10 s counterstain with Papanicolaou's haematoxylin (1:20 in distilled water) was performed. A positive reaction was represented by a dark purple to black cytoplasmic signal as seen in all figures. The number of vang/2-positive Purkinje cells was counted in the lobus caudalis of the cerebellum in an area measuring $160 \mu \mathrm{m} \times 160 \mu \mathrm{m}$ (area '10' in Fig. 1). Control $(n=5)$ was compared to treatment $(n=7)$ using a two-tail unpaired Student's t-test using MINITAB software. The 
number of non-Purkinje cells in the vicinity was also counted in three areas measuring $80 \mu \mathrm{m} \times 80 \mu \mathrm{m}$ for each animal and the mean was used as a representative value for the individual. These control and treatment mean values were also compared with a two-tailed unpaired Student's $t$-test.

Expression of vang/2 in different brain regions: In the telencephalon, small neurons located towards the edges, and larger neurons centrally in the area dorsalis telencephali, pars centralis both exhibited positive signals for vang/2 mRNA (Fig. 2). The different morphological characteristics of these cells were highlighted, as the positive signal was evident throughout the entire cytoplasm (Fig. 2B and C). The small neurons in the anterior region of the forebrain (Fig. 2B) were mainly round, with short, stubby cell processes. The larger, more sparsely arranged neurons of the central telencephalon (posterior forebrain) exhibited more abundant cytoplasm and longer processes (Fig. 2C).

Vang/2 expression was also observed in cells in all tectal layers of the carp midbrain (Fig. 3A). The few neurons present in the stratum fibrosum marginale and the stratum opticum, large neurons in the stratum fibrosum et griseum superficiale, neurons scattered through both the stratum griseum centrale and the stratum album centrale and all neurons of the innermost layer of the tectum, the stratum periventriculare exhibited a positive signal. The ventral thalamus which comprises a heterogenous population of small and larger neurons showed positive signals in both of these cell types (Fig. 3B).

In the cerebellum, Purkinje cells and neurons in the granular and molecular layer were positive for vang/2 (Fig. 3C). Purkinje cells either form a monolayer between the granular and molecular layers or, in the lobus caudalis, are seen scattered within the molecular layer and their large cell bodies and dendritic trees are highlighted by the cytoplasmic vang/2 signal (Fig. 3C). Meningeal cells, modified fibroblasts that cover the outer surface of the brain as part of the leptomeninx/arachnoidea, and ependymal cells, which are glial cells that line the ventricles and are believed to be involved in the directional movement of the cerebrospinal fluid, were both found to express vang/2 (Fig. 3A, C, D).

Effects of noxious stimulation: Vang/2 mRNA was strongly expressed in neurons in the forebrain in both control and treatment fish. The pattern of vangl2 expression in the tectum remained constant in control and treatment fish at both time points. There was an increase in the number of vang/2-positive neurons in the stratum griseum centrale in animals $1.5 \mathrm{~h}$ after treatment, but not $3 \mathrm{~h}$ after treatment (Fig. 4A and B). Expression of vang/2 was observed in the hypothalamus in both control and treatment samples, without any distinct difference between both groups of fish. Expression of vang/2 was detected in Purkinje cells of the cerebellum in control and treatment samples at 1.5 and $3 \mathrm{~h}$, respectively.

The number of vang/2-positive Purkinje cells was counted in an area of the lobus caudalis of the cerebellum measuring $160 \mu \mathrm{m} \times 160 \mu \mathrm{m}$ for each condition. The number of vang/2-positive cells (either neurons or glia) that were not Purkinje cells was also counted in three areas measuring $80 \mu \mathrm{m} \times 80 \mu \mathrm{m}$. There were significantly more vang/2-positive Purkinje cells, with $3.57( \pm 0.48)$ cells counted in treatment animals compared to $1.64( \pm 0.73)$ in control $(P=0.031 ; n$ control $=5, n$ treatment $=7)$ (Figs. $1,4 \mathrm{C}, 4 \mathrm{D})$. There were also noticeably more non-Purkinje cells present in this region in treatment animals, with 3.74 $( \pm 0.95)$ in control compared to $6.19( \pm 1.00)$; however, this difference was not statistically significant $(P=$ $0.109 ; n$ control $=5, n$ treatment $=7$ ).

Expression of vang/2 mRNA was found throughout the brain of the adult common carp in treatment fish, which were subjected to a nociceptive input, as well as their respective controls at 1.5 and $3 \mathrm{~h}$ time points. Strong expression of vang/2 was observed in the forebrain as well as in ependymal cells in all conditions that were examined. In the cerebellum of noxiously stimulated fish, the number of vang/2positive Purkinje cells was increased when compared with controls. Investigations into the localisation of 
vang/2 in the brain have hitherto concentrated on expression during embryogenesis $[13,23,28,29]$. The current study is the first to offer an analysis of vang/2 mRNA expression in the mature carp brain.

Fig. 4. Common carp, (A and B) midbrain, tectum mesencephali ('5' in Fig. 1) RNA-ISH with vang/2 riboprobe, Papanicolaou's haematoxylin counterstain. (A) Control animal; (B) treatment (1.5 h) animal. The stratum griseum centrale (layer between white lines, ' $e$ ' in Fig. 3A) exhibits an increased number of positive neurons in treated animals (1.5 h) compared to control animals. (C and D) Cerebellum ('10' in Fig. 1). (C) Control animal; (D) treatment (1.5 h) animal. The number of positive Purkinje cells (arrows) in treated animals $(1.5 \mathrm{~h})$ is higher than in control animals.

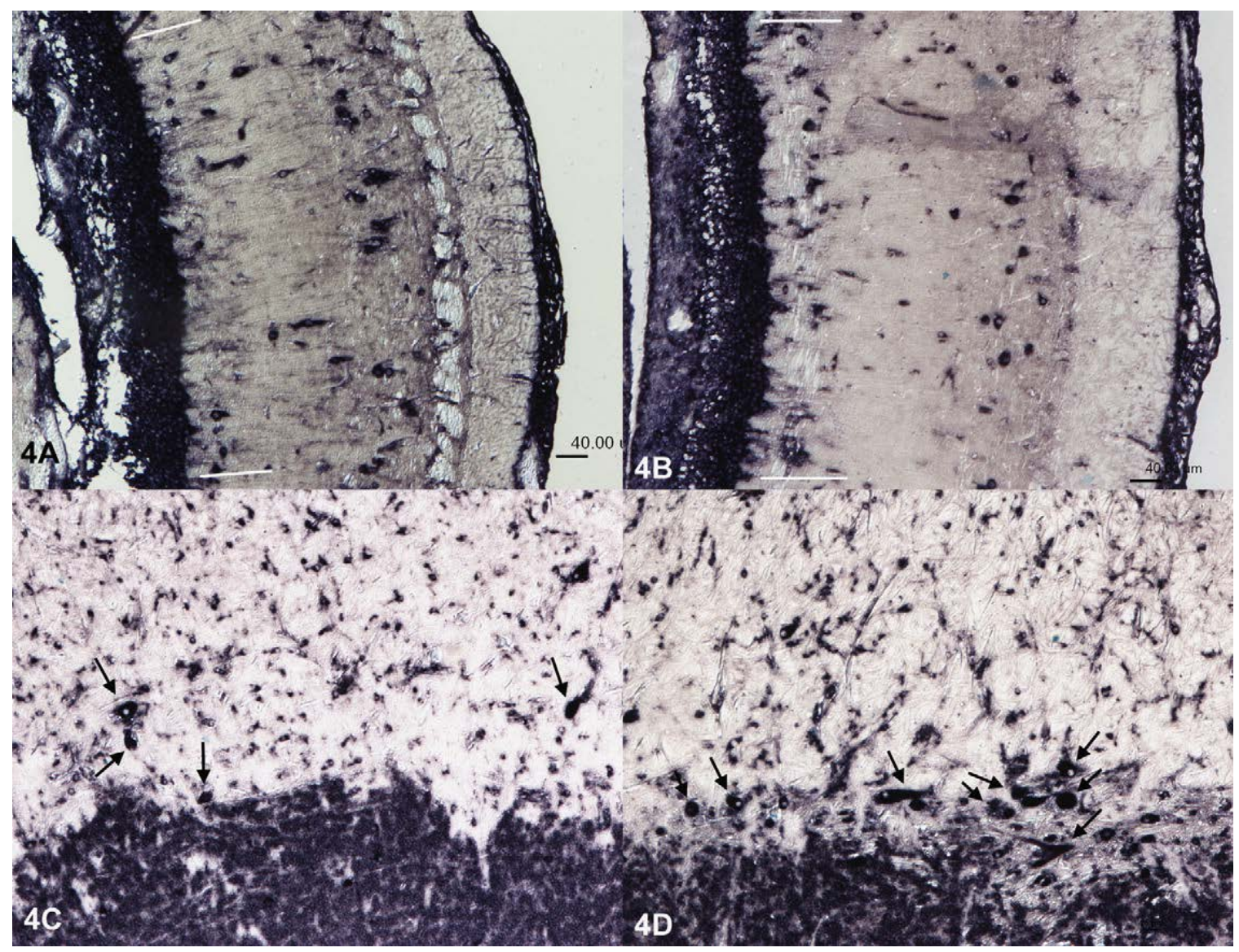

The vangl2 gene was strongly expressed in the ependymal cells of the carp the function of vangl2 in ependymal cells in the mature carp brain might be. One possibility is that expression of vang/2 in the ependymal cells is needed to maintain the integrity of the blood-brain barrier. This suggestion is feasible because modulation of cytoskeleton elements, which can be achieved through vang/2 activation of the JNK pathway [27], is important in maintaining the structure of the blood-brain barrier [17].

In the current study, in situ hybridisation showed that vang/2 mRNA is prevalent in neurons in the telencephalon. This finding is in agreement with previous studies which demonstrated a function of vang/2 in regulating gene expression in the forebrain, where it is essential for the expression of a number of anterior brain gene markers [23]. The homologous region of the telencephalon is the mammalian cerebral cortex, and in the developing mouse embryo, this region was found to express vang/2 protein [30]. In mammals, the forebrain region is intimately associated with the perception and evaluation of noxious stimuli. For example, the forebrain regions of the prefrontal cortex, the anterior cingulate cortex and the 
posterior parietal cortex are activated by the spatial discrimination of pain [22]. The intense expression of vangl2 in the carp forebrain, along with the regulation demonstrated previously, means that it may be modulating the sensory perception through altered expression in the forebrain.

Expression of vang/2 was detected in structures of the midbrain, which are known to be involved in mammalian pain processing. Constitutive expression of vang/2 was detected in the thalamus, which is a major relay station of nociceptive information in mammals [19] and the hypothalamus, which coordinates the endocrine response to nociception [8]. Transcription of vangl2 was also seen in all layers of the optic tectum, most densely in the dura mater, the stratum fibrosum et griseum superficiale and the stratum periventriculare. Most of the afferent fibres of the stratum fibrosum et griseum superficiale originate from retina [32], but this layer also receives input from the cerebellum and other tectal areas [10]. The cells of the stratum periventriculare are small monopolar neurons which give rise to dendrites in the stratum fibrosum et griseum superficiale [21]. Between $4 \%$ and $7 \%$ of the neurons in this layer are cholinergic [31], and a subset display Neuropeptide $Y$ [33]. Therefore, the expression of vang/2 in the tectum has the ability to affect the communication between the tectal layers and also interact with the cellular outputs from the tectum.

The expression pattern of vang/2 in the carp brain is similar to some proteins that are involved in nociception. Proteins such as neuropeptide $Y$ [12], the CB1 receptor [15] and the $\delta$-opioid receptor [4], which modulate nociceptive signalling, are all highly expressed in the telencephalon of cyprinidae and salmonid fish $[5,18,23]$, adding to the data which indicate that the telencephalon may be involved in nociceptive processing in fish [7]. Purkinje cells of the cerebellum expressed vang/2, and the number of cells stained by the vang/2 probe increased in treatment fish compared to controls. The teleost cerebellum has previously been suggested to have a role in nociception as ablation of the goldfish cerebellum results in increased sensitivity to potentially painful stimuli [14]. Additionally, a high number of Purkinje cells were found to express the $\delta$-opioid receptor mRNA [24]. Future in situ hybridization studies assessing whether these genes are co-localized with vang/2 would be useful to determine whether particular cell types are responsible for controlling the response to nociceptive stimuli.

In the context of nociception and pain perception, vang/2-mediated cell signalling in the mature fish could be via the canonical Wnt pathway or the PCP pathway. The PCP pathway interacts with the cytoskeleton to control directionality of novel neurons [11], whereas the canonical Wnt pathway negatively regulates $\beta$ catenin to alter expression of target genes, some of which, for example nitric oxide synthase (NOS) [6], are involved in pain processing [1]. The $\mathrm{Wnt} / \beta$-catenin pathway is activated in the adult mammalian brain during neurogenesis [20] and it would be of interest to assess whether vang/2 is able to modulate neurogenesis in the hippocampus through this pathway, as insight into this process may lead to novel treatments for chronic pain. A number of genes are activated during neurogenesis from $2 \mathrm{~h}$ onwards [9]. As vang/2 was up-regulated at 1.5 and $3 \mathrm{~h}$ after the nociceptive event, then became down-regulated by 6 $\mathrm{h}$ [25], it is possible that vang/2 is contributing to an early response which modulates the neurogenesis pathway.

The expression of vang/2 mRNA was detected throughout the carp brain, particularly in the ependymal cells and the telencephalon. More Purkinje cells expressed vang/2 after nociceptive treatment compared to controls. Due to its anatomical localization and regulation, vang/2 should be further investigated as a novel target potentially involved in central nociceptive processing in higher vertebrates. 


\section{Acknowledgements}

The work was funded by a BBSRC PhD studentship grant and a BBSRC research grant awarded to LUS. We are grateful to Gregor Govan and Jonathan Banks as well as the Histology Laboratory, Veterinary Laboratory Services, Faculty of Veterinary Science, for technical assistance.

\section{References}

[1] M.K. Boettger, N. Uceyler, M. Zelenka, A. Schmitt, A. Reif, Y. Chen, C. Sommer, Differences in inflammatory pain in nNOS-, iNOS- and eNOS-deficient mice, Eur. J. Pain 11 (2007) 810-818.

[2] J. Chen, C.S. Park, S. Tang, Activity-dependent synaptic Wnt release regulates hippocampal long term potentiation, J. Biol. Chem. 281 (2006) 11910-11916.

[3] G.V. De Ferrari, R.T. Moon, The ups and downs of Wnt signaling in prevalent neurological disorders, Oncogene 25 (2006) 7545-7553.

[4] A.H. Dickenson, A.F. Sullivan, R. Knox, J.M. Zajac, B.P. Roques, Opioid receptor subtypes in the rat spinal cord: electrophysiological studies withmu-and deltaopioid receptor agonists in the control of nociception, Brain Res. 413 (1987) 36-44.

[5] C. Doyon, K.M. Gilmour, V.L. Trudeau, T.W. Moon, Corticotropin-releasing factor and neuropeptide Y mRNA levels are elevated in the preoptic area of socially subordinate rainbow trout, Gen. Comp. Endocrinol. 133 (2003) 260-271.

[6] Q. Du, K.S. Park, Z. Guo, P. He, M. Nagashima, L. Shao, R. Sahai, D.A. Geller, S.P. Hussain, Regulation of human nitric oxide synthase 2 expression by Wnt beta-catenin signaling, Cancer Res. 66 (2006) 7024-7031.

[7] R. Dunlop, P. Laming, Mechanoreceptive and nociceptive responses in the central nervous system of goldfish (Carassius auratus) and trout (Oncorhynchus mykiss), J. Pain 6 (2005) 561-568.

[8] D.P. Finn, S.R. Beckett, C.H. Roe, A. Madjd, K.C. Fone, D.A. Kendall, C.A. Marsden, V. Chapman, Effects of coadministration of cannabinoids and morphine on nociceptive behaviour, brain monoamines and HPA axis activity in a rat model of persistent pain, Eur. J. Neurosci. 19 (2004) 678-686.

[9] T.V. Getchell, H. Liu, R.A. Vaishnav, K. Kwong, A.J. Stromberg, M.L. Getchell, Temporal profiling of gene expression during neurogenesis and remodeling in the olfactory epithelium at short intervals after target ablation, J. Neurosci. Res. 80 (2005) 309-329.

[10] B.G. Grover, S.C. Sharma, Organization of extrinsic tectal connections in goldfish (Carassius auratus), J. Comp. Neurol. 196 (1981) 471-488.

[11] C.P. Heisenberg, M. Tada, Wnt signalling: a moving picture emerges from van gogh, Curr. Biol. 12 (2002) R126-128.

[12] X.Y. Hua, J.H. Boublik, M.A. Spicer, J.E. Rivier, M.R. Brown, T.L. Yaksh, The antinociceptive effects of spinally administered neuropeptide $Y$ in the rat: systematic studies on structure-activity relationship, J. Pharmacol. Exp. Ther. 258 (1991) 243-248. 
[13] J.R. Jessen, J. Topczewski, S. Bingham, D.S. Sepich, F. Marlow, A. Chandrasekhar, L. SolnicaKrezel, Zebrafish trilobite identifies new roles for Strabismus in gastrulation and neuronal movements, Nat. Cell Biol. 4 (2002) 610-615.

[14] A.I. Karamyan, Evolution of the function of cerebellum and cerebral hemispheres, Fiziol Zh. SSSR 25, US Dept. Comm. Office Tech. Serv. PB Rep. 31014 (1962) 1-161.

[15] S. Kelly, M.D. Jhaveri, D.R. Sagar, D.A. Kendall, V. Chapman, Activation of peripheral cannabinoid CB1 receptors inhibits mechanically evoked responses of spinal neurons in noninflamed rats and rats with hindpaw inflammation, Eur. J. Neurosci. 18 (2003) 2239-2243.

[16] A. Kipar, H. May, S. Menger, M. Weber, W. Leukert, M. Reinacher, Morphologic features and development of granulomatous vasculitis in feline infectious peritonitis, Vet. Pathol. 42 (2005) 321330 .

[17] U. Kniesel, H. Wolburg, Tight junctions of the blood-brain barrier, Cell. Mol. Neurobiol. 20 (2000) 57-76.

[18] C.S. Lam, S. Rastegar, U. Strahle, Distribution of cannabinoid receptor 1 in the CNS of zebrafish, Neuroscience 138 (2006) 83-95.

[19] H. Leite-Almeida, A. Valle-Fernandes, A. Almeida, Brain projections from the medullary dorsal reticular nucleus: an anterograde and retrograde tracing study in the rat, Neuroscience 140 (2006) 577-595.

[20] D.C. Lie, S.A. Colamarino, H.J. Song, L. Desire, H. Mira, A. Consiglio, E.S. Lein, S. Jessberger, H. Lansford, A.R. Dearie, F.H. Gage, Wnt signalling regulates adult hippocampal neurogenesis, Nature 437 (2005) 1370-1375.

[21] R. Nieuwenhuys, H.J. Ten Donkelaar, C. Nicholson, The Central Nervous System of Vertebrates, vol. 2, Springer, London, 1998, 2219 pp.

[22] Y. Oshiro, A.S. Quevedo, J.G. McHaffie, R.A. Kraft, R.C. Coghill, Brain mechanisms supporting spatial discrimination of pain, J. Neurosci. 27 (2007) 3388-3394.

[23] M. Park, R.T. Moon, The planar cell-polarity gene stbm regulates cell behavior and cell fate in vertebrate embryos, Nat. Cell Biol. 4 (2002) 20-25.

[24] A. Porteros, M. Garcia-Isidoro, A. Barrallo, R. Gonzalez-Sarmiento, R.E. Rodriguez, Expression of ZFOR1, a delta-opioid receptor, in the central nervous system of the zebrafish (Danio rerio), J. Comp. Neurol. 412 (1999) 429-438.

[25] S.C. Reilly, J.P. Quinn, A.R. Cossins, L.U. Sneddon, Novel candidate genes identified in the brain during nociception in common carp (Cyprinus carpio) and rainbow trout (Oncorhynchus mykiss), Neurosci. Lett. 437 (2008) 1350-2138.

[26] S.C. Reilly, J.P. Quinn, A.R. Cossins, L.U. Sneddon, Behavioural analysis of a nociceptive event in fish: comparisons between three species demonstrate species specific responses, Appl. Anim. Behav. Sci. 114 (2008) 248-249.

[27] J. Taylor, N. Abramova, J. Charlton, P.N. Adler, Van Gogh: a new Drosophila tissue polarity gene, Genetics 150 (1998) 199-210. 
[28] F. Tissir, A.M. Goffinet, Expression of planar cell polarity genes during development of the mouse CNS, Eur. J. Neurosci. 23 (2006) 597-607.

[29] E. Torban, H.J. Wang, N. Groulx, P. Gros, Independent mutations in mouse 2 that cause neural tube defects in looptail mice impair interaction with members of the Dishevelled family, J. Biol. Chem. 279 (2004) 52703-52713.

[30] E. Torban, H.J. Wang, A.M. Patenaude, M. Riccomagno, E. Daniels, D. Epstein, P. Gros, Tissue, cellular and sub-cellular localization of the 2 protein during embryonic development: effect of the Lp mutation, Gene Expr. Patterns 7 (2007) 346-354.

[31] N. Tumosa, W.K. Stell, C.D. Johnson, M.L. Epstein, Putative cholinergic interneurons in the optic tectum of goldfish, Brain Res. 370 (1986) 365-369.

[32] H. Vanegas, S.O. Ebbesson, Telencephalic projections in two teleost species, J. Comp. Neurol. 165 (1976) 181-195.

[33] E. Vecino, P. Ekstrom, Distribution of Met-enkephalin, Leu-enkephalin, substance P, neuropeptide $Y$, FMRFamide, and serotonin immunoreactivities in the optic tectum of the Atlantic salmon (Salmo salar L.), J. Comp. Neurol. 299 (1990) 229-241. 